\title{
OPTIMALISASI JENIS OLAHAN KERING DAN CARA PENGOLAHAN AKHIR KETELA
}

\author{
BAMBANG ADMADI HARSOJUWONO, ${ }^{1}$ I GUSTI NGURAH AGUNG ${ }^{2}$ DAN M. SURYA PRAMANA MAHARDIKA ${ }^{3}$ \\ 1 Jurusan Teknologi Industri Pertanian, Fakultas Teknologi Pertanian, Universitas Udayana \\ ${ }^{2,3}$ Jurusan Ilmu dan Teknologi Pangan, Fakultas Teknologi Pertanian, Universitas Udayana \\ E-mail: bambang_harso@yahoo.com
}

\begin{abstract}
ABSTRAK
Penelitian ini bertujuan untuk menentukan efek dari bentuk produk makanan kering serta proses terakhir dari ubi jalar dan interaksinya pada kandungan gizi, ketahanan produk, dan peningkatan kadar glukosa darah dari tikus putih setelah mengkonsumsi produk. Metode pada penelitian ini berdasarkan rancangan acak sempurna dengan 2 faktor eksperimen. Faktor pertama adalah bentuk dari produk makanan kering dengan 4 jenis, yaitu : krispi, chips, cracker dan snack. Faktor kedua adalah proses terakhir dengan 2 jenis metode yang dieksperimenkan dengan membagi ke dalam 8 blok kombinasi perlakuan pada eksperimen. Bentuk krispi dari produk ubi jalar dan proses terakhir dengan oven pembakaran adalah produk terbaik yang dapat meningkatkan kadar gula darah tikus menjadi $8 \mathrm{mg} / L$ dan pati sekitar 39.29\%. Produk ini juga menghasilkan kandungan gizi terbaik meliputi protein, lipid, gula total, dan pati sekitar 3.42\%, 1.79\%, 7.98\%, dan $50.92 \%$.
\end{abstract}

Kata kunci: produk makanan kering, proses akhir, ubi jalar

\begin{abstract}
The research was aimed to determine the effect of the form of dry food products, and final processing of sweet potato and their interaction, on the nutrition content, resistant starch of the products, and the increasing level of blood glucose of mice after consuming the products. The method of the research was based on the completed random design with the factorial experiment two factors were experimented, the first factor was the form of dry food products with four kinds of the product from namely: crispy, chip, cracker and snack. The second factor was final processing with two kinds of methods were experiment was done using so nice which divided into eight blocks of combination treatments of the experiments. The crispy form of dry sweet potato product and final processed by oven roasting was the best product which could suppress the increasing level of blood glucose of mice to $8 \mathrm{mg} / \mathrm{L}$ and has resistant starch of about $39.29 \%$. This product also had the best nutrition content such as content of protein, lipid, total sugar and starch of about $3.42 \%, 1.79 \%, 7.98 \%$, and $50.02 \%$.
\end{abstract}

Key words: dry food products, final processing, sweet potato

\section{PENDAHULUAN}

Pola makan yang berubah tanpa mempertimbangkan keseimbangan gizi, yang mengarah pada konsumsi menu tinggi kalori, kadar lemak tinggi, tetapi kadar karbohidrat kompleksnya rendah, berdampak pada munculnya penyakit degenerative diabetes mellitus. Diabetes mellitus yang telah diderita seseorang tanpa pengobatan yang baik, berkembang menjadi penyakit yang lebih komplek.

Menyimak dari informasi di atas menunjukkan bahwa bahan makanan pokok utama seperti beras, jagung dan sagu, tidak tepat dikonsumsi oleh penderita diabetes mellitus karena tingginya indeks glikemik dan rendahnya kandungan pati resisten. Hal ini juga terjadi pada beberapa bahan pangan berpati lainnya seperti sukun, singkong, pisang, kimpul dan ganyong karena tingginya indeks glikemiknya. Oleh karena itu, perlu dicari bahan makanan alternatif lain yang tersedia untuk pencegahan dan konsumsi penderita diabetes mellitus.

Akhir-akhir ini, umbi-umbian termasuk ketela menjadi perhatian para ahli gizi, masyarakat dan pemerintah dalam hal pemenuhan kecukupan gizi masyarakat dan ketahanan pangan. Hal ini disebabkan kandungan karbohidratnya yang cukup tinggi, mudah tumbuh dan produktifitasnya lebih tinggi dibanding beras. Menurut Nainggolan (2006) umumnya umbi-umbian mempunyai kalori dan kandungan protein yang rendah tetapi kaya akan serat. Selain itu, beberapa jenis umbi-umbian seperti ketela mempunyai kandungan vit $\mathrm{A}$, karotenoid, vit $\mathrm{C}, \mathrm{Ca}$, dan serat lebih baik dibanding beras, maupun bahan pangan pokok lainnya. Bahkan Apriaji (2009) menjelaskan ketela mengandung antioksidan betakaroten, lutein, zeaxantin yang dapat mencegah 
kerusakan sel akibat radikal bebas. Sementara itu, kandungan $\mathrm{Ca}, \mathrm{P}, \mathrm{Fe}$ dan $\mathrm{K}$ pada umbi-umbian dapat mencegah terjadinya hipertensi (Astawan, 2004). Hal ini menunjukkan adanya potensi dari umbi-umbian sebagai bahan pangan diet (rendah kalori), yang disediakan untuk pencegahan timbulnya penyakit diabetes mellitus maupun sebagai bahan pangan untuk konsumsi penderitanya.

Pengolahan ketela dengan berbagai cara perlu dilakukan agar dihasilkan produk yang menarik, diminati, menimbulkan selera bahkan memberikan nilai tambah. Menurut Imam (2008), pengolahan umbi termasuk ketela menjadi olahan kering mempunyai rasa yang lebih enak, meningkatkan nilai gizi serta memberikan daya tarik. Selain itu, pengolahan umbi menyebabkan perubahan komposisi pati resisten akibat gelatinisasi dan retrogradasi pati (Gee et al, 2001) serta perubahan indeks glikemik (Marsono, 2002). Persoalannya adalah belum diketahuinya jenis olahan kering dan cara pengolahan akhir ketela yang mempertahankan kandungan pati resisten, kandungan gizi serta menekan kenaikan gula darah dalam tubuh.

Tujuan penelitian adalah 1) mengetahui pengaruh jenis olahan kering, cara pengolahan akhir ketela dan interaksi keduanya terhadap kandungan gizi dan kadar pati resisten olahan kering ketela serta kenaikan glukosa darah setelah dikonsumsi tubuh, 2) menemukan olahan kering ketela dan cara pengolahan akhir yang tepat sehingga menghasilkan produk yang mengandung pati resisten dan gizi yang tinggi tetapi tidak menyebabkan peningkatan kandungan gula darah yang tinggi.

\section{METODE}

Penentuan jenis olahan kering ketela dan cara pengolahan akhir disusun dalam rancangan acak lengkap dengan percobaan faktorial yang terdiri dari dua faktor yaitu jenis olahan kering yang mempunyai 4 level yaitu keripik, chips, kerupuk dan snack, sedang cara pengolahan akhir mempunyai 2 level yaitu penggorengan dan pengovenan sehingga terdapat 8 perlakuan kombinasi yang diulang 10 kali. Dengan demikian terdapat 80 unit percobaan. Pengujian dilaksanakan secara bioassay menggunakan hewan coba tikus SD sebanyak 80 ekor sebagai unit percobaan dibagi menjadi 8 kelompok perlakuan, masing-masing kelompok terdiri dari 10 ekor sebagai ulangan. Adapun langkah-langkah penelitian sebagai berikut:

\section{Pembuatan pakan standar}

Pakan standar dibuat dengan cara mencampur 620,69 g pati jagung, $140 \mathrm{~g}$ kasein, $100 \mathrm{~g}$ sukrosa, $40 \mathrm{~g}$ minyak kedelai,
$50 \mathrm{~g} \mathrm{CMC}, 35 \mathrm{~g}$ campuran mineral, $10 \mathrm{~g}$ campuran vitamin, $2.5 \mathrm{~g}$ kholin bitartrat dan $1.8 \mathrm{~g}$ L-cystin. Campuran tersebut diadon dengan penambahan air panas sedikit-sedikit jika diperlukan hingga menjadi adonan yang liat. Adonan liat kemudian dicetak dengan mesin cetak pakan /pelet dengan bentuk silinder panjang selanjutnya dikeringkan dalam oven pada suhu $50^{\circ} \mathrm{C}$ selama 12 jam.

\section{Penyiapan hewan coba tikus}

Sebanyak 80 ekor tikus SD yang berumur 3 bulan dengan berat rata-rata $150 \mathrm{~g}$ ditempatkan secara individu dalam kandang-kandang khusus yang terbagi dalam 8 kelompok, sehingga masing-masing kelompok terdapat 10 ekor. Tikus ditempatkan pada tempat yang bersih dalam suhu kamar dengan ventilasi dan pencahayaan yang cukup.

\section{Pemberian pakan standar}

Tikus yang telah ditempatkan dalam kandangkandang khusus selanjutnya diberi pakan standar masing-masing $5 \mathrm{~g}$ per saji dengan diberi minum secara ad libitum (tanpa batas) selama 6 hari.

\section{Pembuatan olahan kering ketela dan pengujian gizinya}

Ketela diolah menjadi keripik, chips, kerupuk dan snack seperti cara berikut ini.

Keripik ketela dibuat dengan cara sebagai berikut: ketela dikupas dan dibersihkan dengan cara mencuci lalu diiris tipis-tipis tebal $1 \mathrm{~mm}$, direndam dalam air kapur 1\% selama 60 menit kemudian dicuci, ditiriskan selanjutnya pengolahan akhir.

Chips ketela dibuat dengan cara sebagai berikut: ketela dikupas dan dibersihkan lalu dikukus dan dihaluskan ditambah backing powder dan tepung tapioka masing-masing 0,5\% dan diadon. Adonan tersebut dikukus hingga matang lalu dibuat lembaran tipis tebal $1 \mathrm{~mm}$, dicetak dan dijemur selanjutnya pengolahan akhir.

Kerupuk ketela dibuat dengan cara sebagai berikut: ketela dikupas dan dibersihkan lalu dikukus dan dihaluskan. Halusan ketela dicampur dengan tepung tapioka $10 \%$, backing powder $0.5 \%$ dan telur $2.5 \%$ kemudian diadon hingga liat lalu dibentuk batangan dengan daun atau plastik, selanjutnya dikukus hingga matang dan didinginkan. Batangan adonan diiris tipis-tipis setebal $2 \mathrm{~mm}$ kemudian dijemur hingga kering, selanjutnya pengolahan akhir.

Snack ketela dibuat dengan cara sebagai berikut: ketela dikupas dan dibersihkan lalu dikukus dan 
dihaluskan. Halusan ketela ditambah tepung terigu $2.5 \%$, telur $2.5 \%$, backing powder $0.5 \%$ kemudian diadon, dicetak selanjutnya pengolahan akhir.

Keripik, chips, kerupuk dan snack setengah jadi tersebut selanjutnya dilakukan pengolahan akhir sesuai perlakuan yaitu penggorengan dan pengovenan, selanjutnya olahan kering ketela siap dijadikan pakan dalam pengujiannya pada tikus.

\section{Penyiapan hewan coba tikus untuk pemberian olahan kering ketela}

Tikus yang telah diberi makan dengan pakan standar selama 6 hari selanjutnya dipuasakan selama 24 jam dalam kandang yang bersih pada suhu kamar dengan ventilasi dan pencahayaan yang cukup.

\section{Pemberian pakan olahan kering ketela}

Tikus yang telah puasa 24 jam, diukur kadar gula darahnya dengan blood glucose test meter. Selanjutnya masing-masing tikus diberi makan olahan kering ketela sesuai perlakuan sebanyak 5 g per saji dengan pemberian minum secara ad libitum (tanpa batas). Setelah tikus makan dilakukan pengambilan darah lagi dalam interval waktu 30, 60, 90, 120 menit.

\section{Pengukuran kandungan gizi, pati resisten, kadar gluksa darah}

Pengukuran dan pengamatan yang dilakukan pada olahan kering ketela yang meliputi kandungan gizi terdiri dari lemak, protein, air, abu, pati, total gula, gula reduksi, pati dan pati resisten. Sedangkan pada darah tikus diukur kadar glukosa darah dan kenaikan kadar glukosa darah.

Data yang dihasilkan dianalisis keragamannya dan dilanjutkan dengan uji perbandingan berganda Duncan. Selanjutnya olahan kering ketela terbaik ditentukan berdasarkan kandungan gizi dan kadar pati resisten tertinggi tinggi tetapi menyebabkan kenaikan glukosa darah terendah.

\section{HASIL DAN PEMBAHASAN}

Pengaruh jenis olahan kering ketela dan car pengolahan akhir terhadap kadar air, abu, protein dan lemak

Analisis keragaman memperlihatkan bahwa jenis olahan kering ketela, cara pengolahan akhir dan interaksinya berpengaruh sangat nyata terhadap kadar air, abu, protein dan lemak. Tabel 1 memperlihatkan adanya perbedaan kadar air, abu, protein dan lemak dari olahan kering ketela yang dibandingkan. Kadar air tertinggi (9.06\%) terdapat pada snack ketela goreng, sedang olahan lain lebih rendah. Kadar abu tertinggi (3.04\%) terdapat pada chips ketela oven, sedang terendah (1.09\%) terdapat pada snack ketela goreng. Kadar protein tertinggi (10.70\%) terdapat pada snack ketela oven, sedang olahan lain lebih rendah. Selanjutnya, keripik ketela oven menunjukkan kadar lemak terendah (1.79\%) sedang olahan lainnya lebih tinggi.

Variasi perbedaan kadar air, abu, protein dan lemak yang terjadi pada olahan kering ketela pada dasarnya disebabkan oleh perbedaan formulasi bahan untuk menghasilkan jenis olahan kering tertentu dan juga cara pengolahan akhirnya. Formulasi bahan dengan menambahkan telur seperti pada pembuatan snack dan kerupuk akan meningkatkan kadar air dan protein. Menurut Matz and Matz (2002), penambahan telur dalam pembuatan biskuit berfungsi sebagai pembentuk tekstur, cita rasa dan meningkatkan gizi khususnya kandungan proteinnya. Begitu halnya dengan penambahan tepung terigu dalam pembuatan snack maka akan juga meningkatkan kadar protein. Hal ini disebabkan terigu mengandung protein dalam bentuk gluten yang cukup tinggi, yaitu antara 8-10\% untuk soft wheat dan 12-15\% untuk hard wheat. Selanjutnya, variasi kadar abu atau mineral sangat dipengaruhi oleh perbedaan penambahan bahan pembantu, karena menurut Harris dan Karmas (1999) perlakuan fisika dan kimia tidak berpengaruh

Tabel 1. Rata-rata kadar air, abu, protein dan lemak dari beberapa olahan kering ketela

\begin{tabular}{|c|c|c|c|c|}
\hline Olahan kering ketela & $\begin{array}{c}\text { Rata-rata kadar air } \\
(\%)\end{array}$ & $\begin{array}{c}\text { Rata-rata kadar abu } \\
(\%)\end{array}$ & $\begin{array}{c}\text { Rata-rata kadar } \\
\text { protein }(\%)\end{array}$ & $\begin{array}{c}\text { Rata-rata kadar } \\
\text { lemak }(\%)\end{array}$ \\
\hline Snack ketela goreng & $9.06 \mathrm{a}$ & $1.09 \mathrm{~d}$ & $7.47 \mathrm{~b}$ & $28.74 \mathrm{a}$ \\
\hline Snack ketela oven & $7.44 \mathrm{~b}$ & $1.54 \mathrm{c}$ & $10.70 \mathrm{a}$ & $7.14 \mathrm{~b}$ \\
\hline Chips ketela goreng & $4.57 \mathrm{~cd}$ & $2.65 b$ & $2.56 \mathrm{~d}$ & $22.91 \mathrm{a}$ \\
\hline Chips ketela oven & $3.25 \mathrm{~d}$ & $3.04 \mathrm{a}$ & $4.21 \mathrm{c}$ & $3.27 \mathrm{bc}$ \\
\hline Kerupuk ketela goreng & $5.56 \mathrm{c}$ & $1.59 \mathrm{c}$ & $2.04 \mathrm{~d}$ & $24.58 \mathrm{a}$ \\
\hline Kerupuk ketela oven & $3.85 \mathrm{~d}$ & $1.82 \mathrm{bc}$ & $2.42 \mathrm{~d}$ & $7.68 \mathrm{~b}$ \\
\hline Keripik ketela goreng & $4.93 \mathrm{~cd}$ & $2.52 \mathrm{~b}$ & $2.25 \mathrm{~d}$ & $26.29 \mathrm{a}$ \\
\hline Keripik ketela oven & $3.27 \mathrm{~d}$ & $2.58 \mathrm{~b}$ & $3.42 \mathrm{~cd}$ & $1.79 \mathrm{c}$ \\
\hline
\end{tabular}

Keterangan: Huruf yang sama di belakang nilai rata-rata pada kolom yang sama menunjukkan perbedaan yang tidak nyata pada tingkat kesalahan $(\alpha) 5 \%$ 
secara nyata terhadap perubahan mineral. Oleh karena itu, penambahan bahan pembantu lebih mempengaruhi proporsi mineral/abu terhadap bahan total. Penambahan bahan pembantu yang lebih tinggi justru menurunkan kadar abu atau mineral olahan kering ketela, karena mineral yang terkandung dalam bahan pembantu jumlahnya jauh lebih kecil dibanding bahan lain yang tekandung dalam bahan pembantu tersebut, akibatnya proporsinya menjadi menurun, seperti terlihat pada Tabel 1. Snack dan kerupuk ketela mempunyai kadar abu yang lebih rendah dibanding chips dan keripik ketela. Cara pengolahan akhir yang menggunakan penggorengan akan meningkatkan kadar minyak. Hal ini disebabkan saat penggorengan akan terjadi penyerapan minyak ke dalam olahan yang digoreng. Tabel 1 memperlihatkan bahwa olahan kering ketela yang mengalami penggorengan mempunyai kadar lemak yang cukup tinggi yaitu berkisar 22.91-28.74\%, sementara olahan yang dioven mempunyai kadar lemak 1.79-7.68\% tergantung dari jenis olahan keringnya.

Kadar protein dan minyak yang tinggi pada olahan kering ketela goreng, pada dasarnya tidak cocok dikonsumsi bagi pencegahan dan konsumsi penderita diabetes mellitus. Menurut Astawan (2009), makanan ringan yang mengandung lemak dan gula tinggi berbahaya bagi yang memiliki riwayat penyakit diabetes mellitus. Sementara itu, Saraswati (2009) menjelaskan bahwa membatasi konsumsi lemak, minyak dan santan hingga seperempat kecukupan energi akan menurunkan resiko diabetes mellitus.

\section{Pengaruh jenis olahan kering ketela dan cara pengolahan akhir terhadap kadar total gula, gula reduksi dan pati}

Analisa keragaman menunjukkan bahwa jenis olahan kering ketela, cara pengolahan akhir dan interaksinya berpengaruh sangat nyata terhadap kadar total gula dan gula reduksi, namun berpengaruh nyata terhadap kadar pati. Tabel 2 memperlihatkan adanya perbedaan total gula, gula reduksi dan pati yang terkandung dalam aneka olahan kering ketela. Kadar total gula tertinggi (12.79\%) terdapat pada chips ketela oven, sedangkan terendah (4.68\%) terdapat pada snack ketela goreng yang tidak berbeda nyata dengan kerupuk ketela goreng. Kadar gula reduksi olahan kering snack, chips, kerupuk dan keripik ketela oven yaitu berkisar 3.35-5.56\% memperlihatkan nilai lebih tinggi dibanding olahan gorengnya yaitu berkisar 2.75-3.75\%, hal ini juga terlihat pada kadar patinya Olahan kering ketela yang dioven mempunyai kadar pati berkisar 50.02-59.05\% sedangkan yang digoreng berkisar 38.44-46.29\%.
Tabel 2. Rata-rata kadar total gula, gula reduksi, dan pati dari beberapa olahan kering ketela

\begin{tabular}{lccc}
\hline \multicolumn{1}{c}{$\begin{array}{c}\text { Olahan kering } \\
\text { ketela }\end{array}$} & $\begin{array}{c}\text { Rata-rata } \\
\text { kadar total } \\
\text { gula (\%) }\end{array}$ & $\begin{array}{c}\text { Rata-rata } \\
\text { kadar gula } \\
\text { reduksi (\%) }\end{array}$ & $\begin{array}{c}\text { Rata-rata } \\
\text { kadar } \\
\text { pati (\%) }\end{array}$ \\
\hline Snack ketela goreng & $4.68 \mathrm{~d}$ & $3.09 \mathrm{~b}$ & $46.29 \mathrm{~b}$ \\
Snack ketela oven & $8.28 \mathrm{~b}$ & $5.44 \mathrm{a}$ & $59.05 \mathrm{a}$ \\
Chips ketela goreng & $5.85 \mathrm{c}$ & $3.65 \mathrm{~b}$ & $38.44 \mathrm{c}$ \\
Chips ketela oven & $12.79 \mathrm{a}$ & $5.39 \mathrm{a}$ & $50.44 \mathrm{a}$ \\
Kerupuk ketela & $5.45 \mathrm{~cd}$ & $3.75 \mathrm{~b}$ & $44.47 \mathrm{~b}$ \\
goreng & & & \\
Kerupuk ketela oven & $8.20 \mathrm{~b}$ & $5.56 \mathrm{a}$ & $55.15 \mathrm{a}$ \\
Keripik ketela goreng & $5.50 \mathrm{c}$ & $2.55 \mathrm{c}$ & $44.51 \mathrm{~b}$ \\
Keripik ketela oven & $7.98 \mathrm{~b}$ & $3.35 \mathrm{~b}$ & $50.02 \mathrm{a}$ \\
\hline
\end{tabular}

Keterangan: Huruf yang sama di belakang nilai rata-rata pada kolom yang sama menunjukkan perbedaan yang tidak nyata pada tingkat kesalahan $(\alpha) 5 \%$

Perbedaan kandungan total gula, gula reduksi dan pati pada dasarnya disebabkan adanya perbedaan formula olahan kering ketela dan pengaruh pengolahan akhir. Pada pembuatan snack, chips dan kerupuk ketela terjadi penambahan terigu untuk snack serta tapioka untuk chips dan kerupuk dengan takaran yang bervariasi (Harsojuwono,2008). Kedua bahan berpati yang ditambahkan ini akan mempengaruhi proporsi total gula, gula reduksi dan pati terhadap bahan total, sedangkan dalam pembuatan keripik tidak dilakukan penambahan bahan tepung tersebut. Sementara itu, dalam proses pengolahan akhir akan terjadi perubahan proporsi komposisi dan tambahan berat total bahan khususnya olahan yang digoreng, yaitu dengan terserapnya sebagian minyak ke dalam produk. Oleh karena itu, kedua hal tersebut sangat mempengaruhi perbedaan kadar total gula, gula reduksi dan pati dari olahan kering ketela yang dibandingkan. Selain itu, terdapat pengaruh lain dari proses pengolahannya, khususnya dalam pembuatan keripik ketela. Menurut Harsojuwono (2008), keripik umbi dibuat melalui tahapan pengirisan tipis-tipis umbi yang dilanjutkan dengan perendaman ke dalam larutan kapur. Pada perendaman dalam larutan kapur ini, sebagian gula reduksi yang terkandung dalam bahan larut dan keluar dari bahan. Menurut Thornburn (2006), gula-gula sederhana baik disakarida maupun monosakarida seperti gula-gula reduksi mempunyai sifat yang larut dalam air. Dengan terjadinya pelarutan ini, maka terjadi penurunan kadar gula reduksi pada pembuatan keripik ketela. Oleh karena itu, keripik ketela kadar gula reduksinya cenderung lebih rendah dibanding produk olahan ketela lainnya. 
Pengaruh jenis olahan kering ketela dan cara pengolahan akhir terhadap pati resisten dan kenaikan glukosa darah

Analisa keragaman menunjukkan bahwa jenis olahan kering ketela, cara pengolahan dan interaksi keduanya berpengaruh sangat nyata terhadap kadar pati resisten dan kenaikan glukosa darah dalam tubuh yang mengkonsumsinya. Tabel 3 memperlihatkan bahwa ada perbedaan kadar pati resisten dari olahan kering yang dibandingkan dan perbedaan kenaikan glukosa darah dalam tubuh yang mengkonsumsinya. Kadar pati resisten tertinggi 39.29\% terdapat dalam keripik ketela oven, sedang terendah terdapat pada snack ketela goreng yang tidak berbeda nyata dengan kerupuk ketela goreng. Sementara itu, kenaikan glukosa darah tertinggi $(60.50 \mathrm{mg} / \mathrm{lt})$ ketika mengkonsumsi snack ketela goreng, sedangkan terendah $(8.00 \mathrm{mg} / \mathrm{lt})$ saat mengkonsumsi keripik ketela oven.

Perbedaan kadar pati resisten tersebut di atas kemungkinan disebabkan proses pengolahan yang berbeda-beda dari olahan kering ketela. Pada pengolahan yang menggunakan panas dan air dalam jumlah yang cukup seperti dalam pembuatan snack, chips dan kerupuk ketela akan menyebabkan pati tergelatinisasi. Menurut Thornburn et al (2006), gelatinisasi pati akan meningkatkan kelarutan dan kecernaan pati, yang artinya dalam proses gelatinisasi ini, kemungkinan sebagian besar pati menjadi tidak resisten. Hal ini yang menyebabkan olahan-olahan ketela tersebut mempunyai kadar pati resisten yang rendah. Sementara itu, dalam pembuatan keripik ketela terjadi penguapan air yang mengakibatkan pengeringan produk. Menurut Meyer (1995), pengeringan produk yang mengandung pati akan menyebabkan penggabungan molekulmolekul amilosa sehingga strukturnya menjadi lebih kompak dan sulit dicerna enzim. Ini artinya terjadi peningkatan kadar pati resisten pada keripik ketela. Menurut Asp (2002), pembentukan pati resisten selama proses pengolahan dipengaruhi oleh kandungan air bahan, $\mathrm{pH}$, suhu dan waktu pemanasan, jumlah siklus pemanasan dan pendinginan, pembekuan dan pengeringan.

Tabel 3 juga memperlihatkan bahwa antar keripik ketela oven dan goreng nampak bahwa kadar pati resisten pada ketela oven lebih tinggi dibanding yang digoreng. Hal ini disebabkan terjadinya perubahan proporsi komposisi dan berat total keripik ketela goreng setelah dilakukan penggorengan karena terjadi penyerapan minyak ke dalam produk, akibatnya perbandingan pati resisten terhadap berat total menurun yang mengakibatkan kadar pati resisten juga menurun.
Tabel 3. Rata-rata kadar pati resisten dan kenaikan glukosa darah

\begin{tabular}{lcc}
\hline \multicolumn{1}{c}{$\begin{array}{c}\text { Olahan kering } \\
\text { ketela }\end{array}$} & $\begin{array}{c}\text { Rata-rata } \\
\text { kadar pati } \\
\text { resisten (\%) }\end{array}$ & $\begin{array}{c}\text { Rata-rata } \\
\text { kenaikan glukosa } \\
\text { darah (mg/lt) }\end{array}$ \\
\hline Snack ketela goreng & $11.12 \mathrm{~d}$ & $60.50 \mathrm{a}$ \\
Snack ketela oven & $17.09 \mathrm{c}$ & $55.00 \mathrm{a}$ \\
Chips ketela goreng & $17.10 \mathrm{c}$ & $40.00 \mathrm{~b}$ \\
Chips ketela oven & $27.50 \mathrm{~b}$ & $34.00 \mathrm{c}$ \\
Kerupuk ketela goreng & $14.14 \mathrm{~cd}$ & $45.50 \mathrm{~b}$ \\
Kerupuk ketela oven & $23.22 \mathrm{~b}$ & $43.00 \mathrm{~b}$ \\
Keripik ketela goreng & $27.52 \mathrm{~b}$ & $22.00 \mathrm{~d}$ \\
Keripik ketela oven & $39.29 \mathrm{a}$ & $8.00 \mathrm{e}$ \\
\hline
\end{tabular}

Keterangan: Huruf yang sama di belakang nilai rata-rata pada kolom yang sama menunjukkan perbedaan yang tidak nyata pada tingkat kesalahan $(\alpha) 5 \%$

Perbedaan kadar pati resisten tersebut ternyata juga mempengaruhi perbedaan kenaikan glukosa darah dalam tubuh setelah mengkonsumsi aneka olahan kering ketela tersebut. Hal ini mungkin disebabkan pati yang terkandung dalam beberapa olahan kering ketela seperti snack, chips dan kerupuk mengalami gelatinisasi sehingga mudah dicerna dan dihidrolisa menjadi glukosa dalam tubuh sehingga menyebabkan kenaikan glukosa darah. Hal ini didukung oleh Denby (2007), yang menjelaskan bahwa zat pati seperti amilosa yang terkandung dalam bahan pangan bila dimasak terlalu lama akan membuat lebih mudah dicerna dan gula dapat dilepaskan dengan cepat ke aliran darah. Sementara itu, olahan kering ketela yang berbentuk keripik dengan pati resisten yang lebih tinggi sulit dicerna dan dihidrolisa menjadi glukosa sehingga kenaikan glukosa darahnya rendah. Hal ini didukung pendapat Marsono (2002), yang menjelaskan bahwa pati resisten yang mempunyai sifat kental seperti serat pangan dapat mengurangi kecepatan absorbs dalam tubuh dan sulit untuk dicerna. Perlambatan pencernaan dan absorbs karbohidrat ini akan menurunkan respon glukosa dalam darah. Sementara itu, Arora (2008) menjelaskan bahwa mengkonsumsi serat larut dan tak larut yang alami sebanyak $50 \mathrm{mg}$ per hari dapat menurunkan kadar glukosa darah hingga $10 \%$.

Kenaikan glukosa darah juga menunjukkan perbedaan antara chips dan keripik ketela goreng dengan cip dan keripik ketela oven. Kedua olahan goreng tersebut menunjukkan kenaikan glukosa darah yang lebih tinggi dari pada yang dioven. Hal ini nampaknya dipengaruhi oleh keberadaan minyak yang cukup tinggi terkandung dalam chips dan keripik ketela goreng. Menurut Arora (2008) keberadaan minyak dalam produk mempengaruhi 
kadar glukosa darah ketika produk dikonsumsi oleh tubuh yang mengalami gangguan fungsi metabolisme yang mengaturnya untuk menghasilkan energi.

Berdasarkan kadar pati resisten tertinggi dan kenaikan glukosa darah terendah, maka olahan ketela yang berbentuk keripik ketela oven terpilih sebagai produk pangan yang cocok untuk pencegahan dan konsumsi penderita diabetes mellitus.

\section{SIMPULAN}

Jenis olahan kering ketela, cara pengolahan dan interaksi keduanya berpengaruh nyata terhadap kadar pati, namun berpengaruh nyata terhadap kadar air, abu, protein, lemak, total gula, gula reduksi, kadar pati resisten dan kenaikan glukosa darah tubuh setelah mengkonsumsi olahan ketela tersebut. Jenis olahan kering ketela dan cara pengolahan akhir yang dapat digunakan untuk pencegahan dan konsumsi penderita diabetes mellitus adalah keripik ketela oven yang memiliki kadar air 3.27\%, abu $2.58 \%$, protein $3.42 \%$, lemak $1.79 \%$, total gula $7.98 \%$, gula reduksi $3.35 \%$, pati 50.02 , pati resisten $39.29 \%$ dan menyebabkan kenaikan glukosa darah sebesar $8 \mathrm{mg} / \mathrm{lt}$.

\section{DAFTAR PUSTAKA}

Arora, A., 2008. Lima Langkah Mencegah dan Mengobati Diabetes. PT Bhuana Ilmu Populer. Jakarta.

Asp, N.G. 2002. Resistant Starch. Eur. J. Clin. Nutr. 46 (Suppl. 2): 1.

Astawan, M., 2009. Kadar Glikemik dalam Makanan ringan. http://www.republika.co.id/ koran/113/66343. Di-access 9 November 2009.

Denby, N., 2007. Glycemic Index and Resistant Starch. http://cuek.wordpress.com/glycemic_index_resistant_ starch.html. Di-access 9 November 2009

Haris, S.R. dan E. Karmas. 1999. Evaluasi Gizi Pada Pengolahan Bahan Pangan. Terbitan kedua. Penerbit ITB, Bandung.

Harsojuwono, B.A. 2008. Pengolahan Aneka Makanan Ringan dari Umbi-umbian. Lembaga Bali Cemerlang Indoguna. Denpasar.

Marsono, Y. 2002. Indeks Glikemik Umbi-umbian. Agritech, vol. 22 (1): 13-16.

Matz, S.A., and T.D. Matz, 2002. Cookies and Cracker Technology. The AVI Publ. Co. Inc. Westport Connecticut.

Meyer, L.H. 1995. Food Chemistry. The Avi Publishing Company, Inc. Wetport. Connecticut.

Saraswati, S., 2009. Diet Sehat. A Plus Books. Depok

Thornburn, A.W., J.C. Brand and A.S. Truswell, 2006. The Glycemic Index of Food. The Medical Journal of Australia, 144: 580-582. 